\title{
Discussion on the Marxism Popularization and Ideological and Political Education Among University Students
}

\author{
Yi Yang and Wenwen Yi \\ Nanchang Key Laboratory of material and structure detection Jiangxi University of Technology
}

Keywords: Marxism; Marxism Popularization; Ideological and Political Education among University Students

\begin{abstract}
National Congress of the CPC report points out to promote the Marxism popularization. To explore the connotation of Marxism popularization, profoundly realize its necessity and realistic possibility, and analyze the relation between Marxism popularization as well as ideological and political education can help us to clear our mind and have a better knowledge and strengthen the ideological and political education. We have to deeply push Marxism popularization, strengthen the mechanism construction for ideological and political education among university students; positively push the Marxism popularization and strengthen the effective carriers to push the team construction. In the course of researching, this paper takes dialectical materialism and historical materialism as guidance.
\end{abstract}

\section{Introduction}

With the advent of social development and the approaching of information era, students are broadening their horizon with more and more channels to acquire knowledge. Meanwhile, students have a strong sense of curiosity and they have breakthroughs in pursuing innovation with active thoughts, aiming to achieve self-development. Besides, students are not mature because they are unilateral and extreme, who are easily affected by the external environment. Moreover, with the rapid development of information technology, a dazzling array of information makes it difficult for people to choose. Affected by social though in western countries, impact of values, there is a glittering array of undesirable phenomenon and students lose their faith with vulgar ideas, distorted values, and missing social responsibilities. In addition, students doubt and deny the Marxist Theory.

Universities are important places for research and study Marxist theory, which can be regarded as its important driver and transmitter, taking on the responsibilities to imbue students with Marxist theory so as to cultivate builders with Chinese features. In the context of Marxism popularization, we have to strengthen Marxist education based on scientific education method of ideological and political education so as to carry out Marxist education through simple and dynamic forms which is not only beneficial for their healthy growth but is also of great significant for promoting the Marxism popularization.

Research on the advancement of Marxism popularization as well as ideological and political education is of vital importance for the growth of university students and the practice of cause of building socialism with Chinese characteristics.

Studying on the Marxism popularization as well as ideological and political education is the inherent requirement to push the Marxism popularization. Historical materialism tells us that people 
are creators of the history while the general public can be regarded as the practical subjectivity. The targets of Marxism popularization are the public and mass. Students are important parts of the mass and the hope of the nation as well as the successors of the Socialist cause, backbones of nation construction. Therefore, we have to master the Marxist theory and analyze complicated social phenomenon with Marxist theory so as to set up the target to contribute to the nation, region and society. In the new era, it is necessary to adopt scientific methods of ideological and political education to popularize Marxism among university students, and strengthen the effectiveness of Marxist education in order to promote the Marxism popularization.

Studying on the Marxism popularization as well as ideological and political education is related to Socialism with Chinese characteristics. Promoting the popularization of Marxism, especially the popularity of Marxism in contemporary China and carrying out outreach activities are requirements to develop the Socialist cause with Chinese characteristics. The hope of the nation depends on young university students, and we have to arm them with theories of socialism with Chinese characteristics which is directly related to the development of the nation as well as the practice of Socialist cause and the great rejuvenation of the Chinese nation.

This paper tries the utmost to correctly understand the connotation and characteristics of Marxism popularization based on studying the relationship between Marxism popularization and ideological and political education among university students so as to comprehensively master the necessity and possibility of pushing forward the Marxism popularization among them. Besides, this paper deeply analyzes the dialectical relation between Marxism popularization and ideological and political education to have a better knowledge of it, strengthen its significant meaning, positively explore the Marxism popularization and effectively improve the ideological and political education.

\section{The connotation and meaning of Marxism popularization}

The reform and opening up, the Chinese party is leading the socialist modernization and meanwhile carrying out activities to promote theme education, keep CPC's advanced education and deeply explore as well as study the scientific concept of development. Based on a series of development activities, we have effectively pushed forward the development of Marxism popularization. At present, the current world condition is stable with profound changes. After the Cold War, international communist movement fallen into the lowest ebb and there is an obvious trend towards a multi-polar world. What's more, the global economy is developing deeply with rapid advancement in terms of science. However, the effects of financial crisis still remain and the power of national force is changing. It is in such context that 17 th Congress of CPC report put forward the calling to promote Marxism popularization, which clearly points out to establish socialist core value system and promote theoretical system of socialism with Chinese characteristics as well as push forward the task to promote Marxism popularization. Based on this, relevant workers started to research on the Marxism popularization with new research results.

Firstly, Marxism popularization proposes the theoretical base to consolidate the ideological and political education. Further strengthening and improving ideological and political education points out, university students are valuable intelligences and improving their ideological and political qualities, constantly strengthening and improving their ideological and political education, and training them to become outstanding builders and successors of the Socialist cause with Chinese characteristics are beneficial to realize the strategy of invigorating the country through science as well as the strategy of reinvigorating China through human resource development. Besides, it can 
ensure that China is always in an unassailable position and helps to realize the construction of a well-off society. Strengthening ideological and political education among university students is helpful to accelerate the target of pushing forward the socialist modernization, which has far-reaching strategic significance. University is a place to cultivate talents which takes on the responsibilities to cultivate builders with all-round development quality. In ideological and political education among students, we have to stick to Marxism popularization and implement it through the whole process based on proper means. In addition, we have to improve their theoretical knowledge based on Mao Zedong thought and theoretical system of socialism with Chinese characteristics so as to help them establish scientific world view, correct philosophy of life and values of life, stimulate their innovative spirit and firm their determination to struggle for the Socialist cause.

Besides, it is helpful to strengthen the close ties between the party and the people and consolidate the party's ruling status. CPC represents the fundamental interests of the mass and the history shows that only the Communist Party can save China, and only the CPC can lead the mass to acquire great achievements in socialist modernization construction. At present, the Western hostile forces create rumors with democracy and human rights as the covers, aiming to split China. Promoting Marxism popularization aims to help more and more people to know the Marxism theory and have a good knowledge of the basic line, principles and policies of the Party so as to expand its covering and make more people participate in political life.

Finally, it is helpful to enrich and develop Marxism theory, and push further development of Marxism theory. Marxism popularization is the target and means as well as the process, which can arm the public so as to make practice.

\section{The necessity and possibility to promote Marxism popularization among university students}

University students are the forces to make the nation become prosper which are active with innovative ability. It is not difficult to see that promoting Marxism popularization among university students is an important sector based on the analysis on connotation and characteristics of Marxism popularization. In addition, analyzing the aim to promote Marxism popularization, understanding its objective inevitability and realistic possibility is very important for us to clear the relation between Marxism popularization and ideological and political education among university students.

As targets of Marxism popularization, young university students should recognize, learn and master Marxism; what's more, as practice objectives, they have to test it and resolve the practical problems; besides, as advocators, they should not only properly use Marxism, but also advocate Marxism, which is the ultimate goal of Marxism popularization.

Pushing forward Marxism popularization among university students is the basic requirement for the Marxist theory, socialism construction with Chinese characteristics and university students' growth.

Promoting Marxism popularization among university students is the requirement for their self-development. University students are in a key period for forming values and philosophy. During this period, knowledge of modern science and technology is very important, yet political quality improvement is also a very important aspect. While fostering high-quality scientific and technological talents, universities should also convey value standards, and beliefs so as to help them establish socialist ideals and beliefs and form common political values. The General Secretary $\mathrm{Hu}$ Jintao, pointed out on the university students meeting in China Agricultural University that they should not only try unremitting efforts to learn professional knowledge but also learn theories of 
socialism with Chinese characteristics; they should not only learn excellent national culture but also embrace excellent culture from abroad; they should not only learn knowledge and skills but also master scientific methods. At present, adopting dynamic and simple approaches to carry out theoretical education of socialism with Chinese characteristics can guarantee their healthy growth, which can be regarded as the base for them to smoothly entering into the society, serve the people as well as the country and realize self-development.

\section{The relation between Marxism popularization and ideological and political education among university students}

Marx once pointed out that once you master the theories, they shall become material strength. Theory is to persuade people. Marxism popularization aims to spread the Marxism with simple words and help them solve practical problems with Marxism theory. Ideological and political education among university students aims to arm students with Marxism to push them change the world and change them to finally cultivate them as the builders of future career.

Marxism popularization has experienced the reform and construction of the Party which has been relatively mature. The suggestion of modern Marxism popularization grants it with new connotation and further consolidates the theoretical base of ideological and political education among university students. Deeply understanding the relation between Marxism popularization and ideological and political education can help us to clear our mind, and realize its important meaning so as to explore effective approaches to strengthen the ideological and political education among university students.

What is the aim for universities to carry out Marxism theoretical education? Firstly, it is helpful to the requirement of modern education. Marxism theory is a scientific value and approach for modern society construction as well as the theoretical base for reform etc. Only by learning Marxism, sticking to Marxism and adopting Marxism can we hold the direction of socialist orientation and keep to make performance. Secondly, it can stick to the task to cultivate high quality talent. Marxism is a scientific value and approach, and mastering Marxism's standpoint, value, approach to analyze social phenomenon, and setting up firm communist belief can be regarded as important standards for their growth.

Ideological and political education among university students is a task with abundant contents, which is very difficult to implement well. Besides, it is the summation of idea system and behaviors for them to accept ideological and political education. The content of ideological and political education takes the political value as the core, which focuses on the actual thought, aiming to solve the real problem. Currently, it should be led by the system of socialist core values so as to help them establish scientific outlook of world and life and strengthen national spirit education, civic and moral education and culture quality education. Marxism does not only ask to focus on the theoretical education but also change the boring discourse system to interesting discourse system, which requires to implement the Marxism popularization.

\section{Promoting Marxism popularization to improve ideological and political education among university students}

University students are the main objects of Marxism popularization, which are forerunners to test its effectiveness. Only when they master the basic theory of Marxism, can they be granted with the power to recognize and change the world to realize its theoretical value and ensure that there will be 
successors of the Socialist cause with Chinese characteristics. Currently, the initiative of learning Marxism is one of the problems because many of them beckon that it is too boring. What's more, some of education means are not proper so students feel tired of it. So how to popularize Marxism among university students is an important topic to strengthen the ideological and political education.

Pushing forward the Marxism popularization among university students is to strengthen the mechanism innovation of ideological and political education, aiming to change the causes and running mode. This mechanism does not only include the interactive relation, function and rules of ideological and political education but also include the relation between Marxism and ideological and political education, ideological and political education and other education etc.

Firstly, we have to establish a coordination mechanism between ideological and political education and other professional educations. University students ' ideological and political education is a systematic project, which is an important part of education and requires every courses to play an educational role so as to work together. Therefore, every university student should bear the responsibility to carry out moral education. Besides, we have to continuously explore ideological and political education resources so as to introduce the party's principles and policies to professional education to help them consciously strengthen self-cultivation, and strive to achieve the political socialization. In academic research, we should stick to professional ethics and professionalism, adhere to classroom discipline, actively promote the policies and principles of party and fight against illegal views. While evaluating professional teachers, we should not only focus on the research results and teaching amount, but also pay attention to the moral role they play which can be tested by questionnaire and attending class. In addition, we have to construct a sound communication system for teachers who are engaged in ideological and political education and professional teachers.

Secondly, we have to foster an education mechanism among everyone in terms of teaching, management and service which refers to the condition to fully play the function of ideological and political education so as to create subtle influence on university students based on natural environment, humanities and employee culture to finally achieve the education target. At present, the mechanism is not completely formed, and each person goes his own way in terms of scientific research, educational administration, management, and student work. It is o doubt that promoting Marxism popularization to strengthen the ideological and political education among university students is a systematic project which needs joint efforts of all faculties and university students. When the student work department is playing its core role, the professional teacher and other functional departments should also play important roles so as to build a new pattern to promote Marxism popularization and strengthen ideological and political education.

\section{Conclusions}

In nearly 90 years when Marxism is introducing into China, Marxism theorists with young people as the main bodies have always been engaged in advocating and studying Marxism. Under the guidance of the Marxist theory the Communist Party has made great achievements in revolution and construction. The fact proves that only Marxism can save China and only when Marxism is popularized, can the public be armed with this theoretical weapon to serve the socialist construction. At present, university students are important forces who are builders of the socialist construction.

When facing complicated condition at home and abroad, the Marxism education should pay attention to the effectively promote and advocate Marxism. This paper takes the task suggested by the $17^{\text {th }}$ CPC report as the background to comb the relation between Marxism popularization and ideological 
and political education so as to seek effective means such as mechanism innovation, approach innovation, carrier innovation, class innovation, student community, social practice, school culture and internet construction etc, aiming to effectively promote Marxism popularization and strengthen ideological and political education. Of course, there is a long way to go and only by constantly innovating and following the pace of times can students' ideological and political education be satisfied.

\section{Acknowledgment}

This work was supported by Project on professional and characteristical construction of Jiangxi province 2010 (Civil Engineering) and Project on the planning and construction of disciplines in Jiangxi University of Technology (Structure Engineering)

\section{References}

[1] Marx and Engels: Selected Works (Volume1-4 ) 「M」Beijing: the People's Publishing House, 1995.

[2] Selected Works of Lenin. (Volume1-4) Beijing: the People's Publishing House, 1995.

[3] Selected Works of Mao Tse-tung. (Volume1-5) Beijing: the People's Publishing House, 1991 (Edition 2)

[4] Selected Works of Deng Xiaoping. (Volume 3). Beijing: the People's Publishing House, 1993 (Edition 1)

[5] The Selected Works of Jiang Zemin (Volume 1-3) $\lceil\mathrm{M}\rfloor$. Beijing : the People's Publishing House, 2006 (Edition 1)

[6] Charles Horton Cooley. Human Nature and the Social Order[M] Huaxia Publishing House, 1999

[7] $\mathrm{Hu}$ Jintao. Holding high the great banner of socialism with Chinese characteristics, striving for new victories in building a moderately prosperous society in all respects- 17th CPC Report. Beijing: the People's Publishing House, 2007.

[8] Deng Shaoping. On the Medium in the Course of Thought and Politics Education [M]. Beijing: China Social Sciences Press, 2007.

[9] Zhang Yaocan, Zheng Yongting, Luo Yuting etc. Modern thought politic education[M]. Beijing: the People's Publishing House, 2006

[10]Peng Xiaolin, Ni Xianmin etc. Innovation of ideological and political education among University students under the condition of higher education popularization[M]. Sichuan: Sichuan University Press, 2009 